\title{
Eessõna
}

\section{Kirjaoskuste kirevus}

Inimühiskonnas ja eluslooduses üldiselt on konkurentsieelis neil, kes on kohanemisvõimelised, valmis vajaduse järgi juurde ja ümber õppima, lahendama keerulisi, sageli üheainsa õige vastuseta ülesandeid, on loovad ja julgevad ellu viia uusi ideid. Oskus ja soov lahendada keerulisi olukordi toetab nii ühiskonnas kodanikuna osalemist kui ka edukust tööturul (OECD, 2016; 2018; 2019). OECD andmetel on enam kui kümnendik olemasolevatest töökohtadest juba praegu automatiseeritud. Ligi veerand töökohtadest eeldavad olulisi muudatusi lähitulevikus, ligi pool kaob tõenäoliselt juba järgneva 25 aasta jooksul. Tekkib palju uusi töökohti ja ameteid, mille pidamine eeldab uusi, varem tavatuid teadmisi ja oskusi.

Et aidata õpilastel ja õpetajatel nende muutustega toime tulla, vajab õpikäsitus seni teadaolevate ja uute lähenemiste mõtestatud ning oskuslikku lõimimist. Üheks kiiresti arenevaks valdkonnaks haridusalastes uurimustes, mis seda ülesannet täita püüab, on kirjaoskus ja selle liigid.

Esialgu märkis kirjaoskuse mõiste inimese võimet lugeda ja kirjutada. Sajandite eest oli see Euroopas ka kohustusliku alg- ja põhihariduse kehtestamise peamine eesmärk (Talts \& Mikser 2013). Aja jooksul on kirjaoskuse mõiste haridusteadustes ja -praktikas suuresti laienenud - esialgu metafoorina, seejärel üha selgemalt piiritletud teaduslik-teoreetilise konstruktsioonina. Mõiste on osutunud rahvusvaheliselt sedavõrd menukaks, et praegu on vaevalt võimalik ühes ajakirjanumbris või mahukas kogumikuski vähegi ammendavalt käsitleda kõiki kasutusel olevaid kirjaoskuse liike ja tõlgendusi. Seda enam on vaja eri lähenemisi tunda, soodustada arutelu nende üle ning otsida ühisosa. See ajakirjanumber keskendubki kirjaoskuse eri liikidele ja käsitustele.

Inimese kirjaoskus mistahes valdkonnas muutub ja areneb aja jooksul ning seda mõjutavad mitmesugused tegurid. Kirjaoskuse kujunemine on järkjärguline ja aeganõudev nähtus ning seetõttu on kirjaoskuse eri liikide üks olulisimaid uurimissuundi kirjaoskuse tasemed. Nende väljaselgitamisele on suunatud mitmed rahvusvahelised võrdlusuuringud (näiteks PISA), samuti ópilaste suuremahuline testimine (näiteks e-hindamine Eestis). Tasemete eristamisele saab omakorda läheneda eri teoreetilistelt alustelt (Kärbla et al., 2018; Rannikmäe et al., 2017). Ka mõned selle numbri artiklid keskenduvad kirjaoskuse asjaomase liigi tasemete eristusele. 


\section{Mida pakub siinne erinumber?}

Sissejuhatavas artiklis tutvustab Jari Lavonen Soome põhikooli õppekava rolli loodusteadusliku kirjaoskuse kujundamisel. Ta käsitleb ülekantavate oskuste näiteks kriitilise ja loova mõtlemise oskuse - kujundamist ning selgitab, kuidas need on seotud loodusteadusliku kirjaoskusega. Artikkel aitab kaasa strateegia „Haridus 2030“ mõistmisele ja selles tutvustatud kaheksa võtmepädevuse laiemale mõistmisele ja olulisusele erinevate kirjaoskuste maailmas (OECD, 2018).

Traditsiooniliste kirjaoskustest on artiklid funktsionaalsest ehk toimetulekualasest kirjaoskusest (laiendatuna emakeele kirjaoskusele), õpilaste karjääriteadlikkuse kui loodusteadusliku kirjaoskuse kujundamisest ning matemaatikaalasest pädevusest, mis autorite interpretatsioonis asendab selles artiklis matemaatilise kirjaoskuse.

Helin Puksand ja Krista Uibu keskenduvad neidude ja noormeeste funktsionaalse lugemisoskuse erinevustele, mis ilmnesid 15-aastaste õpilastega 2018. aastal tehtud PISA uuringu tulemustest. Teksti iseloomustava situatsiooni ja tekstitüübi ning ülesande lahendamisel eeldatava kognitiivse protsessi alusel osutusid tüdrukute tulemused poiste omadest paremaks. Artikkel on abiks õpetajatele õpilaste funktsionaalse lugemisoskuse arendamisel.

Regina Soobard, Ana Valdmann, Rain Mikser ja Miia Rannikmäe käsitlevad loodusainete õpetajate valmisolekut kasutada õpilaste karjääriteadlikkust edendavaid stsenaariume loodusteadusliku kirjaoskuse arendamisel. Õpilaste valmidus kavandada oma tulevast karjäri on üha olulisem. Samas on uuringud näidanud, et sellele pööratakse loodusainete tundides vähem tähelepanu kui teistele loodusteadusliku kirjaoskuse osadele. Artikkel selgitab vajalikku edasist arengut õpetajate teadmistes ja mõtteviisis, et õpilaste karjääriteadlikkusele senisest enam kaasa aidata.

Marje Johanson, Margus Pedaste, Merlin Pastak, Karin Täht, Maarja Sõrmus ja Hannes Jukk annavad ülevaate matemaatikapädevuse käsitustest Eestis ja rahvusvaheliselt, samuti tutvustavad matemaatikapädevuse hindamise raamistikku rahvusvahelistes võrdlusuuringutes. Empiirilises osas analüüsivad autorid Eesti põhikooli teise kooliastme matemaatika e-tasemetöid ning teevad järeldusi selle kohta, milliseid alampädevusi tasemetööd eelkõige käsitlesid. Tulemused aitavad avada matemaatikapädevust kui üldpädevust ning toetada pädevuse hindamist tasemetöödes ja õpetajate igapäevatöös.

Suhteliselt uudsete kirjaoskuse valdkondadena on mitme artikli keskmes finantskirjaoskus ja ettevõtluskirjaoskus. Ka need on üha olulisemad ühiskonna kiirelt areneva majanduse toetamiseks ja inimeste isiklikuks toimetulekuks keerukas, sageli ettearvamatus majanduskeskkonnas. Kati Voomets, Leonore Riitsalu ja Andra Siibak keskenduvad küsimusele, kuidas sotsiaalmeedia abil 
arendada finantskirjaoskust ehk rahvakeeli rahatarkust. Intervjueerides sellenimelisse Facebooki gruppi kuuluvaid inimesi, tuvastasid autorid, et grupis suhtlemine avardas selle liikmete teadmisi ning arendas nende rahandusalase käitumise oskust. Autorid rõhutavad, et kuulumine sotsiaalmeedia gruppi võib mõjuda arendavalt ka pikaajalisele finantskäitumisele, ent selle kinnituseks on vaja edasisi lisauuringuid.

Olav Aarna, Leonore Riitsalu ja Urve Venesaare artikkel on kontseptuaalne - autorite eesmärk on finantspädevuse kui elukestva õppe võtmepädevuste raamistiku loomine. Selleks on autorid analüüsinud rahvusvahelist teaduskirjandust, samuti mitme riigi, Euroopa Liidu ja OECD hariduspoliitilisi ja -administratiivseid dokumente. Loodetavalt võimaldab raamistiku rakendamine elukestva finantshariduse senisest järjekindlamat kavandamist ja selle tulemuslikkuse hindamist.

Külli Hiiemäe-Metsar, Mervi Raudsaar ja Krista Uibu selgitavad, kuidas liigituvad ülesanded, millega arendatakse Eesti gümnaasiumiõpilaste ettevõtluspädevuse alapädevusi. Autorid analüüsisid ettevõtlusprogrammi Junior Achievement ülesandeid, tuginedes üleeuroopalisele raamistikule European Entrepreneurship Competence Framework (EntreComp). Selgus, et motivatsiooni, riskijulgust ja loovust arendavad nimetatud kogu ülesanded ebapiisavalt. See tulemus esitab uurijatele väljakutse teoreetiliselt põhjendatud uute kogude koostamiseks.

Valdkondadeüleste kirjaoskusena on ajakirjas tutvustatud digipädevuse dimensioone, kehalist kirjaoskust ja uurimistööalast kirjaoskust, millest viimasest on eestikeeles teaduskirjanduses seni veel vähe kirjutatud.

Margus Pedaste, Veronika Kalmuse ja Katariina Vainoneni uuring keskendub põhikooliõpilaste digipädevuste mõõdetele ja selgitab, milliste ülesannetega saab põhikooliõpilaste digipädevust hinnata. Uuringu tulemusena on alust loota, et digipädevuse dimensioone osatakse tasakaalustatult hinnata ning selleks hindamiseks valida ja koostada sobivaid ülesandeid.

Kirjaoskuse seni suhteliselt vähe käsitletud valdkondade hulka kuulub ka kehaline kirjaoskus. Tuginedes rahvusvahelistele teadusuuringutele, annavad Maret Pihu, Henri Tilga ja Merike Kull ülevaate kehalise kirjaoskuse olemusest ja komponentidest. Kirjeldades eri riikide koolides korraldatud uuringuid, näitlikustavad autorid, kuidas kehalise kirjaoskuse arendamise eesmärk on luua eeldused, et inimene oskaks tervislikult elada ning kasutada tervisliku eluviisiga kaasnevaid arenguvõimalusi.

Liina Malva ja Äli Leijen selgitavad, millised on Eesti õpetajate ning õpetajakoolituse eriala õppejõudude ja üliõpilaste uurimistööalased teadmised ning kuidas õpetajad kasutavad uurimistööalast kirjaoskust õpetajatöös. Tulemused näitavad, et tegevõpetajad rakendavad uurimistööalaseid teadmisi 
eelkõige õpilaste uurimistööga seotud ülesannete koostamisel, märksa vähem aga omaenda õpetamispraktikas. Seetõttu vajavad õpetajad suuremat tuge uurimistööalase kirjaoskuse väljakujunemiseks.

Siinse erinumbri lõpus tutvustavad Larissa Jõgi ja Rain Mikser selle aasta alguses ilmunud raamatut „Andragoogika. Raamat täiskasvanu õppimisest ja õpetamisest“. Raamat esitab seni eesti keeles ilmunuist kõige terviklikuma ja süsteemsema käsituse andragoogika mõtteloost ja põhiteemadest.

Miia Rannikmäe, Rain Mikser ja Krista Uibu

\section{Kasutatud kirjandus}

Kärbla, T., Uibu, K., \& Männamaa, M. (2018). Pikilõikeline sissevaade eesti keele taseme- ja eksamitööde tekstimõistmisülesannetesse. Eesti Haridusteaduste Ajakiri. Estonian Journal of Education, 6(1), 157-178.

https://doi.org/10.12697/eha.2018.6.1.07

OECD (2005). Definition and selection of competencies (DeSeCo): Executive summary. Paris OECD Publishing. Vaadatud aadressil http://www.oecd.org/pisa/35070367.pdf.

OECD. (2016). PISA 2015 Results (Volume I): Excellence and Equity in Education. Paris: OECD Publishing.

OECD. (2019). PISA 2018 Results (Volume II): Where All Students Can Succeed.

OECD. (2018). The Future of Education and skills: Education 2030. Paris: OECD Publishing.

Rannikmäe, M., Soobard, R., Reiska, P., Rannikmäe, A., \& Holbrook, J. (2017). Õpilaste loodusteadusliku kirjaoskuse tasemete muutus gümnaasiumiõpingute jooksul. Eesti Haridusteaduste Ajakiri, 5(1), 59-98. https://doi.org/10.12697/eha.2017.5.1.03

Talts, L., \& Mikser, R. (2013) Alg- ja põhiharidus. Mikser, R. (koost), Haridusleksikon (15-22). Tallinn: Eesti Keele Sihtasutus. 